\title{
Fabrication and performance of atmospheric plasma sprayed solid oxide fuel cells with liquid antimony anodes
}

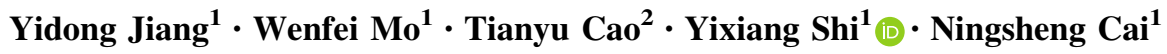

Received: 20 July 2020/Revised: 30 September 2020/Accepted: 13 April 2021 / Published online: 30 April 2021

(C) The Author(s) 2021

\begin{abstract}
A solid oxide fuel cell (SOFC) with a liquid antimony anode (LAA) is a potential energy conversion technology for the use of impurity-containing fuels. Atmospheric plasma spraying (APS) technology has become a promising LAASOFC preparation method because of its economy and convenience. In this paper, button SOFCs with different cathode materials and ratios of pore former were prepared by the APS method and were operated at $750{ }^{\circ} \mathrm{C}$. The effect of the cathode structure on the electrochemical performance of the LAA-SOFCs was analyzed, and an optimized spraying method for LAA-SOFCs was developed. A tubular LAA-SOFC was prepared using the APS method based on the optimized spraying method, and a peak power of $2.5 \mathrm{~W}$ was reached. The tubular cell was also measured at a constant current of $2 \mathrm{~A}$ for $20 \mathrm{~h}$ and was fed with a sulfur-containing fuel to demonstrate its impurity resistance and electrode stability.
\end{abstract}

Keywords Solid oxide fuel cells · Liquid antimony anodes · Atmospheric plasma spraying $\cdot$ Pore former

\section{Introduction}

Solid carbon fuels are widely utilized due to their high yield and low price (Wall 2005; Zhu et al. 2020). However, they have obvious disadvantages when they are employed in fuel cells, such as the severe contact between solid carbon particles and solid anodes, limited fuel transportation in the anode reaction chamber, and their complex poisoning effects (Cao et al. 2017; Thomas and Manoj 2020; Wang et al. 2014c). Integrated gasification fuel cell (IGFC) technology combines electrochemical reactions with thermal cycles for power generation, thereby realizing the indirect electrochemical utilization of coal and greatly

Yixiang Shi

shyx@mail.tsinghua.edu.cn

1 Key Laboratory for Thermal Science and Power Engineering of the Ministry of Education, Department of Energy and Power Engineering, Tsinghua University, Beijing 100084, China

2 Chemical and Biomolecular Engineering, University of Pennsylvania, Philadelphia, PA 19104, USA improving the efficiency of coal power generation (Dong et al. 2019; Li et al. 2010).

In an IGFC system, the coals are first converted into syngas (mainly consisting of $\mathrm{CO}, \mathrm{H}_{2}, \mathrm{CO}_{2}$, and $\mathrm{CH}_{4}$ ) by a flowing gasifying agent ( $\mathrm{Li}$ et al. 2014). The generated syngas is sent into the purification unit for desulfurization and dedusting. Then, the purified syngas is fed into the anode chamber of high-temperature solid oxide fuel cells (SOFCs), where it reacts with oxygen ions from the cathode (Fan and Han 2014). In fuel cells, most of the combustible components in syngas are converted into electricity and heat by particular reactions. Then the unconverted syngas is sent to a combustion furnace for power generation via a thermal cycle.

Liquid metal anode SOFCs are a promising technology for converting fuels containing sulfur and ash. Using such anodes, the cost for impurity removal in IGFC systems can be reduced. To find suitable anode materials with decent electrochemical performance for SOFCs, Sn (Tao et al. 2007; Wang et al. 2014b), Sb (Duan et al. 2016; Jayakumar et al. 2011), Ag (Javadekar et al. 2012), and Bi (Jayakumar et al. 2010) have been previously studied. Sb is an 
attractive choice for liquid metal anodes. Compared to $\mathrm{Bi}$ $\left(0.45 \mathrm{~V}\right.$ at $\left.700{ }^{\circ} \mathrm{C}\right)$ and $\mathrm{Ag}(0.3 \mathrm{~V})$, the liquid antimony anode (LAA) has an adequate open-circuit voltage $(0.75 \mathrm{~V})$. Furthermore, the melting points of $\mathrm{Sb}\left(630^{\circ} \mathrm{C}\right)$ and its oxide $\left(\mathrm{Sb}_{2} \mathrm{O}_{3}, 656{ }^{\circ} \mathrm{C}\right)$ are more easily attained compared to these other metals. In contrast, the product of Sn oxidation $\left(\mathrm{SnO}_{2}\right)$ has a melting point of $1630{ }^{\circ} \mathrm{C}$, which impedes further electrochemical reactions (Wang et al. 2014b). Jayakumar et al. (2011) developed an SOFC with an LAA. The working principle of the LAAs is shown in Fig. 1. If syngas is used as the fuel, the circular reactions in the LAAs are represented as:

$$
\begin{aligned}
\mathrm{Sb}+\frac{3}{2} \mathrm{O}^{2-} \rightarrow & \frac{1}{2} \mathrm{Sb}_{2} \mathrm{O}_{3}+3 \mathrm{e}^{-} \\
\frac{m+n}{3} \mathrm{Sb}_{2} \mathrm{O}_{3}+n \mathrm{CO}+m \mathrm{H}_{2} \rightarrow & \frac{2(m+n)}{3} \mathrm{Sb}+n \mathrm{CO}_{2} \\
& +m \mathrm{H}_{2} \mathrm{O}
\end{aligned}
$$

Because the density of $\mathrm{Sb}_{2} \mathrm{O}_{3}$ is less than $\mathrm{Sb}$, the $\mathrm{Sb}_{2} \mathrm{O}_{3}$ generated at the anode-electrolyte interface can float to the surface of the LAA. Once the floating $\mathrm{Sb}_{2} \mathrm{O}_{3}$ is reduced to metallic antimony by fuels (through the reaction shown in Eq. (2)), the generated antimony will sink to the electrochemical reaction region due to its high density. This reaction cycle between $\mathrm{Sb}_{2} \mathrm{O}_{3}$ and $\mathrm{Sb}$ enables the fuel cell to continuously operate while avoiding the impact of ash on SOFC performance. The relatively large amount of anode material (more than $10 \mathrm{~g}$ antimony per $\mathrm{cm}^{2}$ reaction area in the current research) keeps the electrochemical performance of the SOFC stable even if part of the liquid metal reacts with the sulfur that is present in the fuels (Jiang et al. 2020). In previous studies, the kinetics of the anode-electrolyte interfacial reactions and the antimony oxidation process were analyzed (Wang et al. 2013, 2014c), and a tubular LAA-SOFC was found to have potential for an expanded reaction area (Cao et al. 2019). However, some studies have reported significant hot corrosion of sintered electrolyte due to liquid antimony (Jayakumar et al. 2013; Ma et al. 2019). Therefore, the fabrication of corrosion-proof electrolytes is crucial.

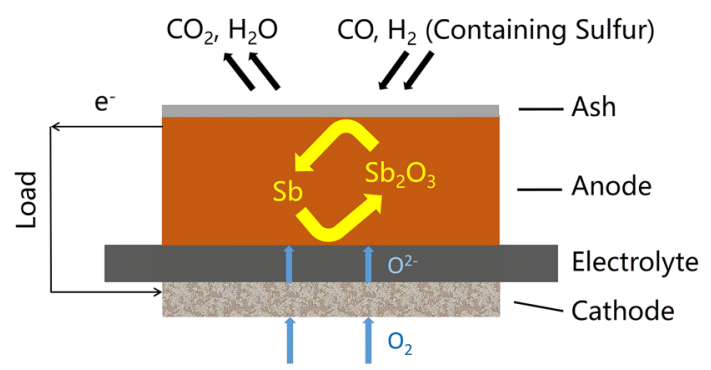

Fig. 1 Working principle of liquid antimony anodes
Atmospheric plasma spraying (APS) is a widely adopted surface layer preparation technology used to create thermal barrier coatings and surface protection layers. In the preparation of SOFCs, APS is used to deposit cell components on porous metal or cermet supports (Henne 2007; Zhang et al. 2017). In addition, it produces electrolyte layers that effectively resist the corrosion of liquid metals and their oxides, which suggests that it may be a promising method for the preparation of durable electrolytes for LAA-SOFCs (Cao et al. 2018). For most plasma-sprayed SOFCs, anodes are deposited on the support and cathodes are prepared at the outermost layer of the cell. However, in regard to LAA-SOFCs, the cathodes should be prepared between the support and electrolyte because the LAA is not stable between these two layers. These types of electrode arrangement strategies are termed anode-down and cathode-down, respectively (Metcalfe et al. 2013). In two previous studies (Cao et al. 2019; Waldbillig and Kesler 2011), the polarization impedance of plasma-sprayed cathode-down fuel cells was relatively large, and ex situ characterization showed that the cathodes had low porosity that could be increased by preparing them with low torch power and long spray distance. Nevertheless, the bond strength of those cathodes decreased, which made the coating crack or break off in the subsequent electrolyte preparation. Therefore, cathode porosity should be improved using other methods, such as adding a pore former into the cathode powder. Carbon black is a popular pore former in this context because of its high melting point and decent oxidizability. Tsai et al. (2014) prepared an APS LSCF-LSGM $\left(\mathrm{La}_{0.58} \mathrm{Sr}_{0.4} \mathrm{Co}_{0.2} \mathrm{Fe}_{0.8} \mathrm{O}_{3-\delta}-\mathrm{La}_{0.8}\right.$ $\left.\mathrm{Sr}_{0.2} \mathrm{Ga}_{0.8} \mathrm{Mg}_{0.2} \mathrm{O}_{3-\delta}\right)$ composite cathode with a polarization resistance of $0.128 \Omega \mathrm{cm}^{2}$ at $750{ }^{\circ} \mathrm{C}$. The cathode was deposited at the outermost layer with $15 \mathrm{wt} \%$ carbon black as a pore former. Harris et al. (2017) prepared LSCF-SDC $\left(\mathrm{La}_{0.6} \mathrm{Sr}_{0.4} \mathrm{Co}_{0.2} \mathrm{Fe}_{0.8} \mathrm{O}_{3-\delta}-\mathrm{Ce}_{0.8} \mathrm{Sm}_{0.2} \mathrm{O}_{1.9}\right)$ cathodes using the APS method with $25 \mathrm{wt} \%$ carbon black as a pore former; the polarization resistance was $0.37 \Omega \mathrm{cm}^{2}$ at $750{ }^{\circ} \mathrm{C}$. However, for cathode-down plasma-sprayed SOFCs, the ratio of pore former in cathode powder still needs to be optimized.

In this study, button LAA-SOFCs with different cathode materials and ratios of pore former were prepared using the APS method and were tested at $750{ }^{\circ} \mathrm{C}$. The effect of the cathode structure on the electrochemical performance of cathode-down APS fuel cells was analyzed, and an optimized spraying method was developed. In addition, a tubular LAA-SOFC was prepared using the optimized APS spraying method. It was tested for $20 \mathrm{~h}$ with a sulfurcontaining fuel to demonstrate the stability of the electrodes. 


\section{Experimental preparation}

Two configurations of the LAA-SOFCs were prepared and characterized. Button fuel cells $(25 \mathrm{~mm} \times 25 \mathrm{~mm} \times 1.8$ $\mathrm{mm}$ ) were prepared for optimizing the coating manufacturing process, and a tubular fuel cell (diameter: $25 \mathrm{~mm}$, length: $200 \mathrm{~mm}$ ) was prepared for enlargement.

\subsection{APS button LAA-SOFC preparation and characterization}

The plasma-sprayed cathodes and electrolyte of the LAASOFC were prepared on stainless steel substrates with a porosity of $20 \% \pm 2 \%$. This manufacturing method is described in a previous work (Cao et al. 2019).

For the button fuel cells, porous cathodes were deposited on stainless steel substrates using the APS (Zhen-Bang Aerospace Precision Machinery Co., Ltd., China) method. The cathode powder (LSCF, $\mathrm{La}_{0.6} \mathrm{Sr}_{0.4} \mathrm{Co}_{0.2} \mathrm{Fe}_{0.8} \mathrm{O}_{3-\delta}$, Qingdao Tianyao Materials Co., Ltd., China) used for cathode spraying contained $15 \mathrm{wt} \%, 10 \mathrm{wt} \%, 5 \mathrm{wt} \%$, and $0 \mathrm{wt} \%$ carbon black as the pore former to make the cathode layer porous (hereafter, LSCF10, LSCF5, and LSCF0, respectively). LSM $\left(\mathrm{La}_{0.8} \mathrm{Sr}_{0.2} \mathrm{MnO}_{3-\delta}\right.$, Qingdao Tianyao Materials Co., Ltd., China) powder with $10 \mathrm{wt} \%$ carbon black was also used for spraying as a control group to evaluate the difference in cathodes (hereafter, LSM10). The thicknesses of the cathodes were all approximately $20 \mu \mathrm{m}$. The electrolyte was prepared using the same APS system as the cathodes. The powder used for electrolyte spraying was $8 \mathrm{YSZ}\left(8 \mathrm{~mol} \% \quad \mathrm{Y}_{2} \mathrm{O}_{3}-\mathrm{ZrO}_{2}\right.$, Qingdao Tianyao Materials Co., Ltd., China), and the thickness of the electrolyte was approximately $100 \mu \mathrm{m}$. Other parameters of the APS method are listed in Table 1.

The testing setup used for the sprayed button cells is detailed in previous work (Jiang et al. 2019). The electrochemical performances of the button cells were measured using the four-probe method with an electrochemical workstation (IM6ex, Zahner-Elektrik GmbH, Germany). The LAA-SOFCs should be operated above $656^{\circ} \mathrm{C}$ (the melting point of the $\mathrm{Sb}_{2} \mathrm{O}_{3}$ ) to protect the anode-electrolyte interface from $\mathrm{Sb}_{2} \mathrm{O}_{3}$ deposition. Meanwhile, the

Table 1 Atmospheric plasma spraying parameters

\begin{tabular}{lll}
\hline Parameter & Value of cathode & Value of electrolyte \\
\hline Torch power $(\mathrm{kW})$ & 30 & 45 \\
Torch current $(\mathrm{A})$ & 550 & 700 \\
Flow rate of $\mathrm{Ar}(\mathrm{slpm})$ & 50 & 45 \\
Flow rate of $\mathrm{H}_{2}(\mathrm{slpm})$ & 0 & 5 \\
Spray distance $(\mathrm{mm})$ & 110 & 80 \\
Powder feed rate $(\mathrm{g} / \mathrm{min})$ & 25 & 10 \\
\hline
\end{tabular}

LAA-SOFC with the SUS430 support could not be operated above $800{ }^{\circ} \mathrm{C}$ because the support was set at the cathode side and the stainless steel would be rapidly oxidized at such temperatures. Therefore, the present LAASOFCs were only suitable for operating at $700{ }^{\circ} \mathrm{C}$ or $750{ }^{\circ} \mathrm{C}$, and we tested the cells at the latter in the present study, achieving a decent performance. The polarization curves of the cells were measured at a speed of $10 \mathrm{mV} / \mathrm{s}$, and the finishing test voltage was $0.2 \mathrm{~V}$. The electrochemical impedance spectra (EIS) of the cells were measured at the open-circuit voltage. The amplitude during the EIS testing was $20 \mathrm{mV}$, and the frequency ranged from $100 \mathrm{kHz}$ to $0.1 \mathrm{~Hz}$. In the button cell experiments, an $\mathrm{Ar}$ gas flow was fed into the anode chamber at a flow rate of 20 standard-state cubic centimeters per minute ( $\mathrm{sccm}$ ), and at the cathode side, oxygen was provided by convection in the furnace. No fuel was supplied during the experiments. An optimized preparation method was employed by measuring the electrochemical performance of the button cells with different cathodes.

After the tests, the button cells were removed from the reactors, cut vertically, fixed in an epoxy mold, and then polished with sandpaper for scanning electron microscopy (SEM). Then the sample was characterized by SEM (Zeiss Merlin VP compact, Germany) to obtain cross-sectional images of the fuel cells.

\subsection{APS tubular LAA-SOFC preparation and characterization}

The tubular fuel cell was prepared via the same stainless steel substrate manufacturing and APS method as the button cells. The optimized preparation method from the button cell experiments was used for preparing the cathode of the tubular cell, and the thicknesses of the cathode and electrolyte were consistent with those of the button fuel cells.

The set-up for the tubular fuel cell is shown in Fig. 2. An SUS430 stainless steel tube was connected to the metal support of the tubular fuel cell as both the current collector and air channel. Then, $1500 \mathrm{~g}$ antimony powder (500 mesh, Changsha Tianjiu Metal Material Co., Ltd., China) was loaded into an alumina crucible. The crucible was fixed in a vertical tube furnace and heated at $750{ }^{\circ} \mathrm{C}$ for $10 \mathrm{~h}$. An Ar gas flow was fed into the crucible during the heating process at a rate of $100 \mathrm{sccm}$ to prevent the antimony from being oxidized, and air flow was fed into the tubular cell at a flow rate of $100 \mathrm{sccm}$. After the antimony was completely melted, the fuel cell was inserted into the liquid antimony bath at a speed of approximately $0.1 \mathrm{~cm} / \mathrm{s}$ until the cell touched the bottom of the crucible. The calculated depth of the liquid antimony bath was $7.6 \mathrm{~cm}$. Two graphite rods, mainly shielded in alumina tubes to avoid 
oxidation by the antimony oxide, were employed for current collection at the anode.

The electrochemical performances of the tubular cell were measured by the same electrochemical workstation as the button cells at $750{ }^{\circ} \mathrm{C}$. The polarization curves and EIS were also measured using the same methods as the button cells. Constant current discharge was measured with the tubular cell at a current of $2 \mathrm{~A}$ for $20 \mathrm{~h}$. During the tubular cell experiment, the flow rates were $50 \mathrm{sccm}$ for the $\mathrm{Ar}$ flow and $400 \mathrm{sccm}$ for the air flow. Deashed taixi anthracite coal (Shenhua Ningxia Coal Industry Group Co., Ltd, China) was supplied to the antimony bath as the fuel. Coal $(10 \mathrm{~g})$ was added to the anode chamber at the beginning of the constant current test and $10 \mathrm{~h}$ after the test began. The tubular cell was pulled out from the liquid antimony bath at a speed of approximately $0.1 \mathrm{~cm} / \mathrm{s}$ after all of the tests were finished.

\section{Results and discussion}

\subsection{Performance of the button LAA-SOFC}

Figure 3 shows the polarization curves and the EIS results of the button fuel cells with different amounts of pore former. The LSCF10 cell reached a peak power density of $70 \mathrm{~mW} / \mathrm{cm}^{2}$, while the peak power densities of the LSCF5 and LSCF0 cells were only 62 and $46 \mathrm{~mW} / \mathrm{cm}^{2}$, respectively. The ohmic resistance of the LSCF5 and LSCF0 cells were both approximately $1.2 \Omega \mathrm{cm}^{2}$, and that of the LSCF10 cell was $1.3 \Omega \mathrm{cm}^{2}$. The polarization impedance of the LSCF10 cell was approximately $0.63 \Omega \mathrm{cm}^{2}$, smaller than that of the LSCF5 $\left(1.1 \Omega \mathrm{cm}^{2}\right)$ and LSCF0 $\left(1.6 \Omega \mathrm{cm}^{2}\right)$ cells. Jayakumar et al. (2011) reported the

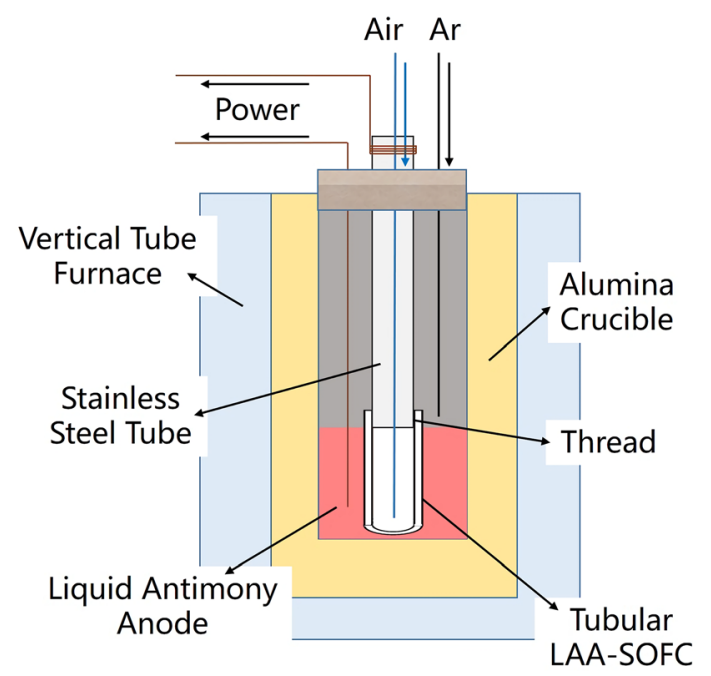

Fig. 2 Electrochemical testing setup for the sprayed tubular LAASOFC polarization impedance of the LAA was approximately $0.06 \Omega \mathrm{cm}^{2}$. This impedance accounted for $3 \%-10 \%$ of the total polarization impedance in the present LAA-SOFCs. Therefore, in the Nyquist diagrams of the EIS results, the two semicircles of each cell were both caused by the cathodes. The different performances of the button fuel cells indicate that the different amounts of pore former in the spraying powder influenced the polarization impedance of the cathode. The impedance data of LSCF0 show an obvious Warburg-type impedance, which suggests a scarcity of mass-transport channels in the cathode. The significant difference in the impedance data among the three cells is a result of the different amounts of pore former in the sprayed powder. The sufficient mass transport in the LSCF10 cathode provides it with better performance than that of LSCF5 and LSCF0.

The cathodes of the button fuel cells were characterized by SEM after the electrochemical tests (Fig. 4). The porosity of the cathode in the LSCF0 cell (Fig. 4a) was very low, and it was difficult for air to diffuse through the cathode layer, resulting in a relatively significant Nernst
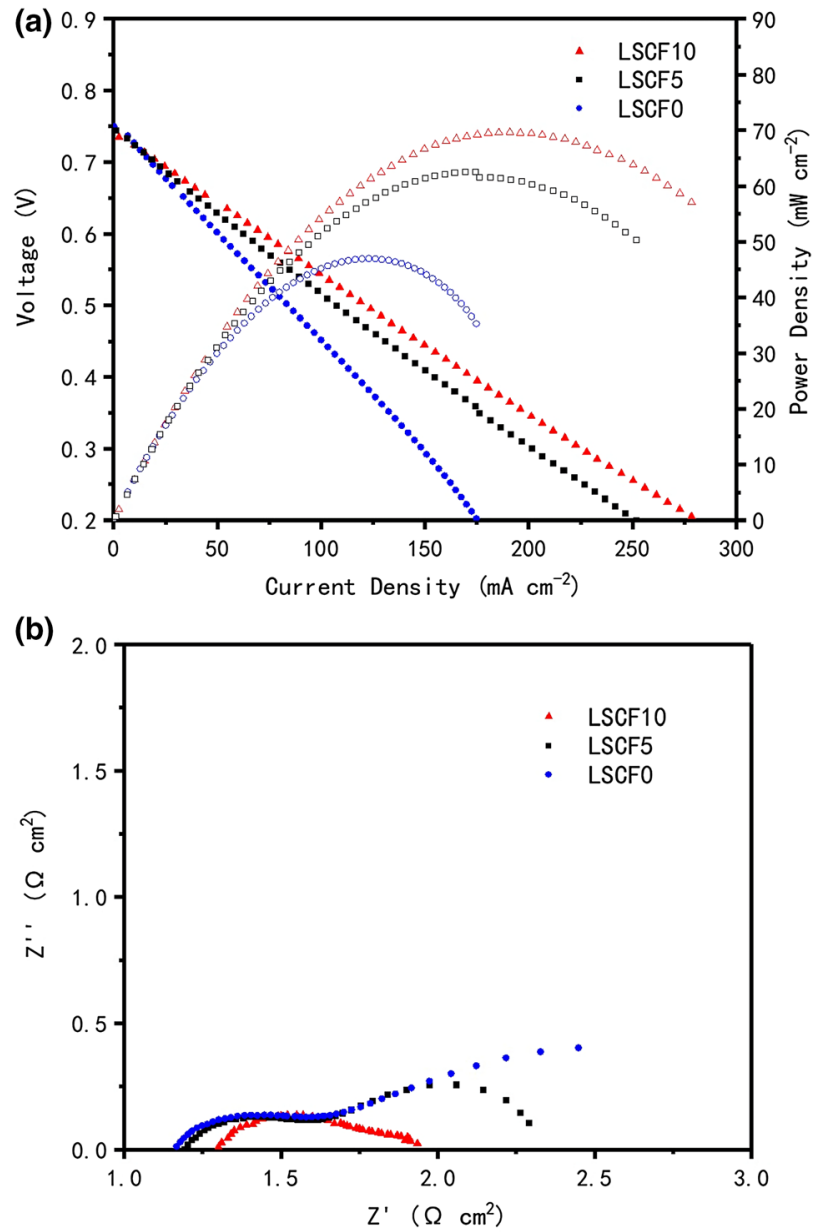

Fig. 3 Polarization curves a and EIS results b of LSCF cathode button fuel cells with different amounts of pore former 

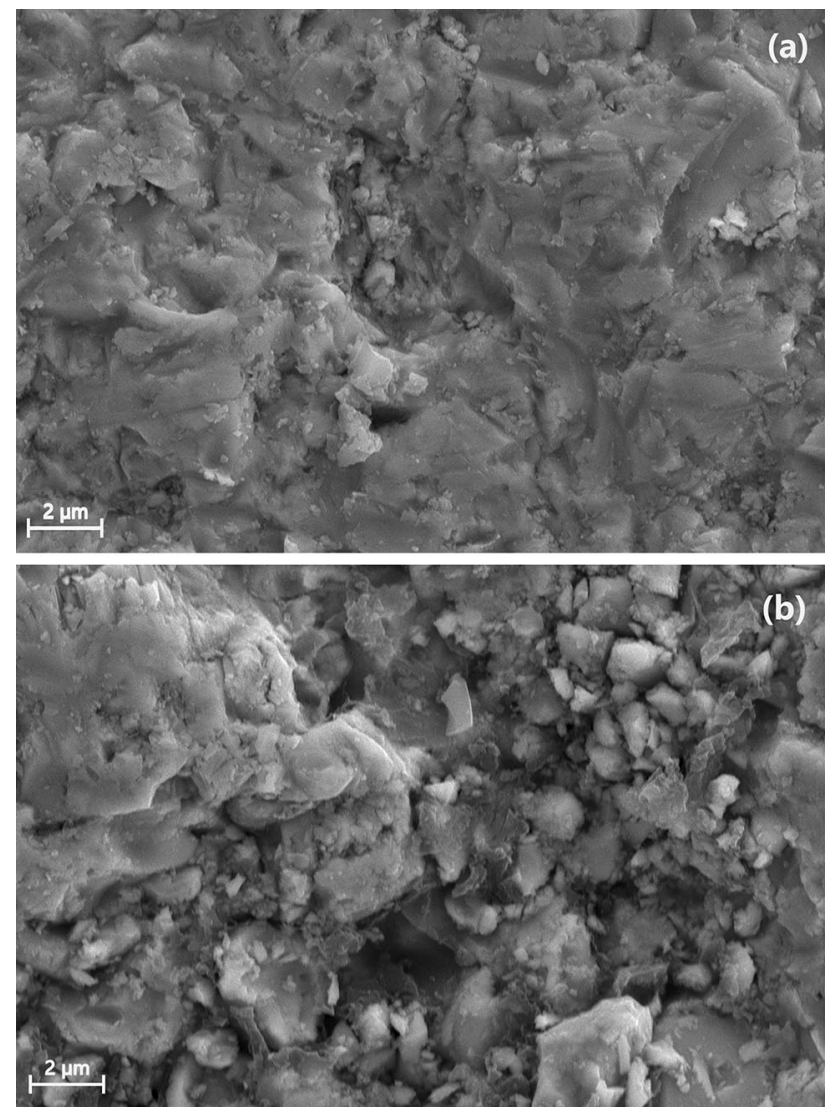

Fig. 4 SEM images of the cathode in LSCF0 $\mathbf{a}$ and LSCF10 cells $\mathbf{b}$

diffusion impedance. That porosity of the cathode in the LSCF10 cell was increased by adding pore former to the spraying powder, and the diffusion impedance decreased accordingly. However, the high content of pore former in the spraying powder resulted in relatively poor contact between the cathode particles and led to an increase in ohmic impedance.

Figure 5 shows the polarization curves and EIS results of the button fuel cells with the LSCF10 cathode and LSM10 cathode. The peak power density of the LSM10 cell was only $29 \mathrm{~mW} / \mathrm{cm}^{2}$, far less than that of the LSCF10 cell. However, the ohmic impedance of the LSM10 cell was much larger than that of the LSCF10 cell. This result can be attributed to the mixed electronic and ionic conductivities of the LSCF material (Zhang et al. 2016), which greatly expanded the reaction interface for oxygen reduction at the cathode of the cell. By contrast, the LSM material (Miruszewski et al. 2016) only conducts electrons at the working temperatures of the SOFCs.

Next, we compared the LAA-SOFC with the LSCF10 cathode to the plasma-sprayed SOFCs using different electrode arrangement types (Table 2). The polarization impedance of the cathode-down cells was much larger than that of the anode-down cells. In previous studies, cathodes of anode-down cells were prepared using a low torch
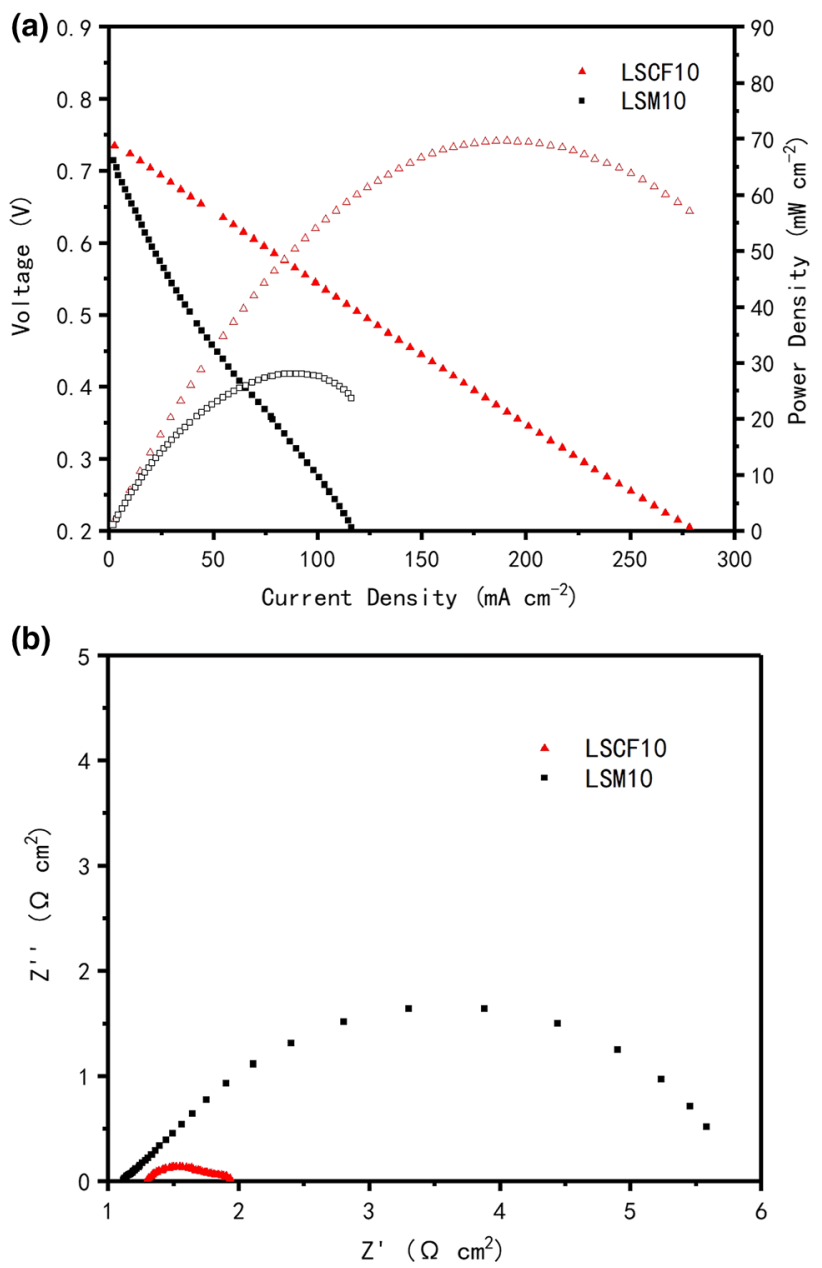

Fig. 5 Polarization curves a and EIS results $\mathbf{b}$ of the button fuel cells with the LSCF10 and LSM10 cathodes

power and a long spray distance, so the cathode particles were semi-molten when reaching the substrates; this made the cathode layers porous but also decreased their bond strength. For such cathodes, a low bond strength is generally acceptable because they are utilized in the outermost layer of fuel cells. However, for cathode-down cells, if the bond strength is low, the heat and impact of the plasma torch would make the coating crack or break off. Therefore, such cathodes are prepared with a relatively high torch power, which results in a lower porosity and a larger polarization impedance. In the present research, with the addition of pore former, the porosity and the performance of the cathode was improved.

\subsection{Performance of the tubular LAA-SOFC}

The tubular LAA-SOFC was fabricated with an LSCF10 cathode because of its respectable electrochemical performance in the button cell experiments. Figure 6 shows a cross-sectional SEM image of the tubular LAA-SOFC. The 
Table 2 Comparison of plasma-sprayed SOFCs with different electrode arrangement types

\begin{tabular}{|c|c|c|c|c|c|}
\hline Authors & $\begin{array}{l}\text { Cathode } \\
\text { materials }\end{array}$ & Spraying method & Type & Pore former & $\begin{array}{l}\text { Polarization } \\
\text { impedance at } \\
750{ }^{\circ} \mathrm{C}\left(\Omega \mathrm{cm}^{2}\right)\end{array}$ \\
\hline Tsai et al. (2014) & LSCF-LSGM & Atmospheric plasma spraying & Anode-down & $15 \mathrm{wt} \%$ carbon black & 0.128 \\
\hline Wang et al. (2020) & LSCF & Atmospheric plasma spraying & Anode-down & None & 0.15 \\
\hline \multirow[t]{2}{*}{ Harris et al. (2017) } & \multirow[t]{2}{*}{ LSCF-SDC } & \multirow[t]{2}{*}{ Atmospheric plasma spraying } & \multirow[t]{2}{*}{ Anode-down } & $25 \mathrm{wt} \%$ carbon black & 0.37 \\
\hline & & & & None & 0.41 \\
\hline Fan et al. (2016) & LSCF & Suspension plasma spraying & Symmetrical cell & 0.3 wt $\%$ carbon black & 0.062 \\
\hline Waldbillig and Kesler (2011) & LSM-YSZ & Suspension plasma spraying & Cathode-down & None & 0.75 \\
\hline \multirow[t]{2}{*}{ Metcalfe et al. (2013) } & \multirow[t]{2}{*}{ LSCF-SDC } & \multirow[t]{2}{*}{ Atmospheric plasma spraying } & Cathode-down & None & 4.1 \\
\hline & & & Anode-down & None & 0.13 \\
\hline Present study & LSCF & Atmospheric plasma spraying & Cathode-down & $10 \mathrm{wt} \%$ carbon black & 0.63 \\
\hline
\end{tabular}

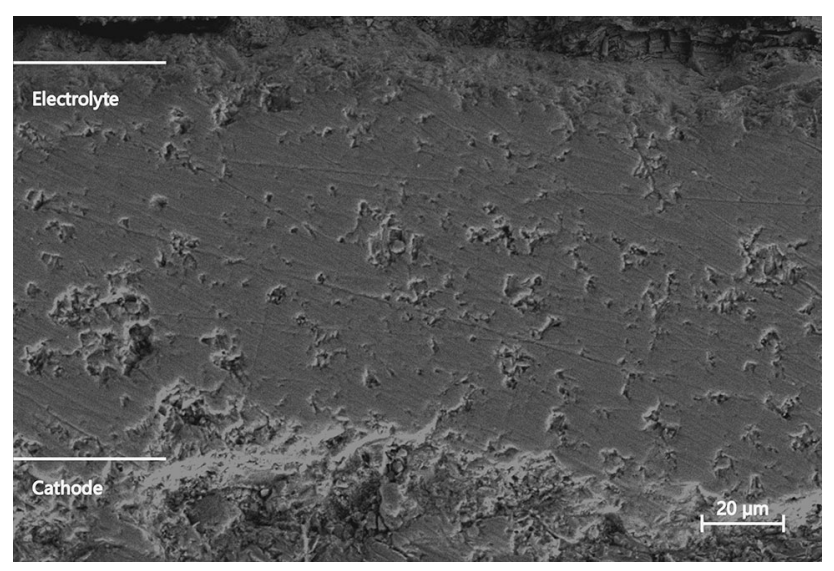

Fig. 6 Cross-sectional SEM image of the tubular LAA-SOFC

calculated reaction area of the tubular cell was $59.7 \mathrm{~cm}^{2}$. Figure 7 shows its voltage during the $20 \mathrm{~h}$ constant current test. The voltage decreased from 0.62 to approximately $0.55 \mathrm{~V}$ during the first $8 \mathrm{~h}$ and remained stable for the following $12 \mathrm{~h}$. Figure 8 shows the polarization curves and EIS results measured before and after the constant current test. The peak power before the test was approximately $2.5 \mathrm{~W}$, which decreased to approximately $1.8 \mathrm{~W}$ after the test. The decrease in the output power was mainly due to the increase in the ohmic impedance, which increased significantly from 36 to $53 \mathrm{~m} \Omega$; the polarization impedance increased slightly from 21 to $25 \mathrm{~m} \Omega$. According to the ex situ analysis, the increase in ohmic impedance was mainly caused by the oxidation of the threaded joint between the tubular cell and the air channel. The ohmic impedance of the tubular cell could be stabilized by optimizing the connection methods, for example, by welding the joint between the metal support and the stainless-steel gas inlet tube.

The operating power density of the current tubular LAA-SOFC was relatively low (approximately $20.9 \mathrm{~mW} /$

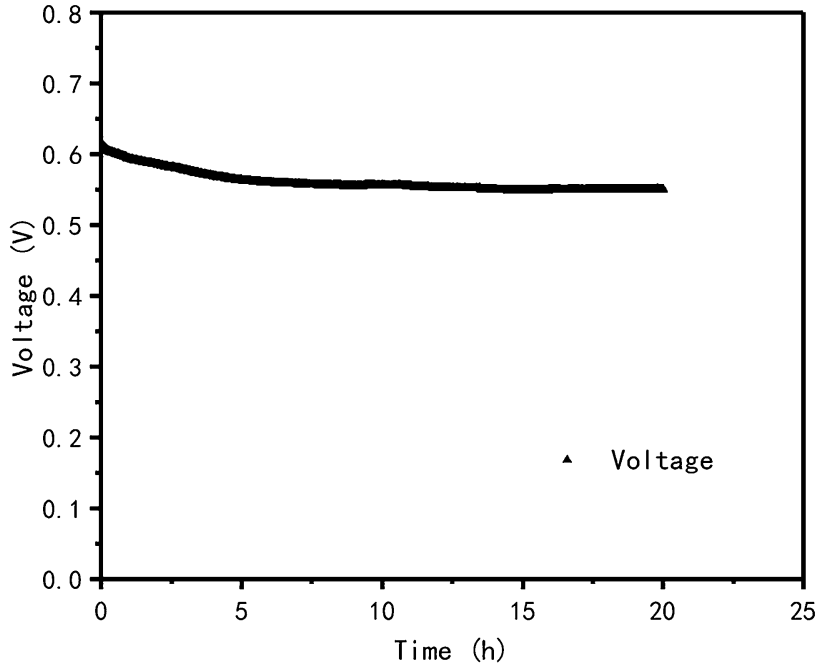

Fig. 7 Voltage of the tubular fuel cell during the $20 \mathrm{~h}$ constant current test

$\mathrm{cm}^{2}$ ). However, the LAA-SOFC showed an energy efficiency of $54.3 \%$, as assessed via a previously described calculation method (Cao et al. 2019). In that method, the energy efficiency of the LAA-SOFC is the product of the fuel efficiency, the theoretical efficiency, and the voltage efficiency. (Wang et al. 2014a) reported the fuel efficiency of the Taixi coal in the LAA was approximately $97 \%$ benefiting from the solid state of the coal and the balance of the coal oxidation. With regard to theoretical efficiency, the heat requirement of the $\mathrm{Sb}_{2} \mathrm{O}_{3}$ reduction reaction could be provided by $\mathrm{Sb}$ oxidation because of the large thermal capacity and the high thermal conductivity of the liquid antimony bath. Hence, the theoretical efficiency of the LAA-SOFC could be calculated by dividing the change in the Gibbs free energy Sb oxidation $(\Delta G,-74.25 \mathrm{~kJ}$ per mol electron transfer at $1023 \mathrm{~K}$ ) by the change in enthalpy $(\Delta H,-98.66 \mathrm{~kJ}$ per mol electron transfer at $1023 \mathrm{~K})$ of 


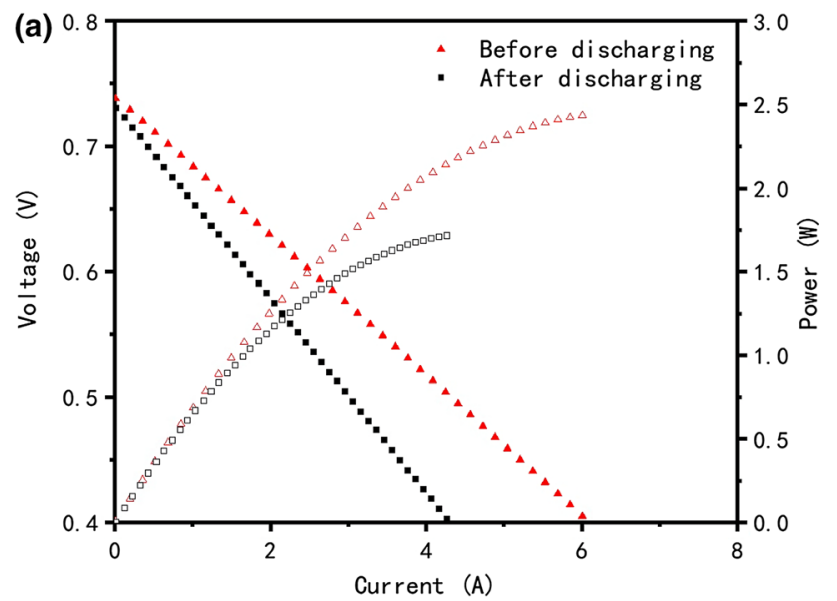

(b)

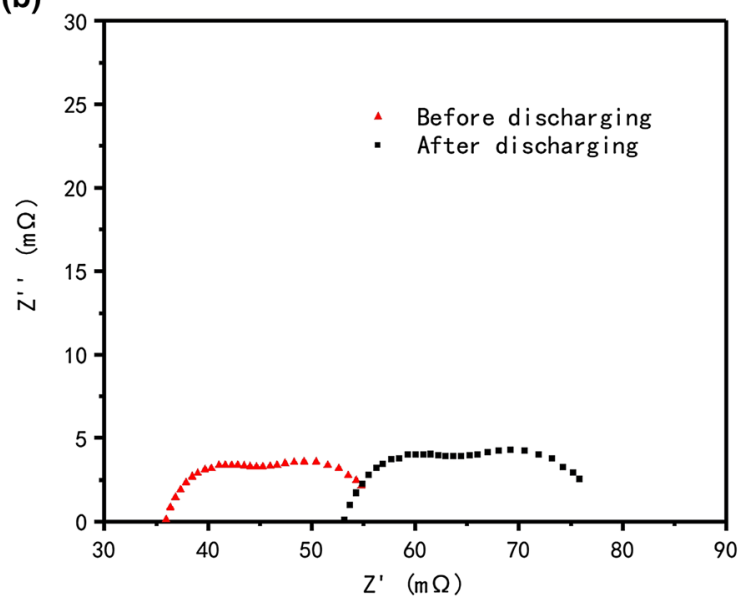

Fig. 8 Polarization curves a and EIS results $\mathbf{b}$ of the tubular LAASOFC measured before and after the constant current test

carbon oxidation in air, resulting in a value of $75.3 \%$. The cell operating voltage at the end of the $20 \mathrm{~h}$ constant current test was $0.55 \mathrm{~V}$, so the voltage efficiency was $74.3 \%$. To estimate the size of the LAA-SOFC stack, we assumed that the spacings between two adjacent cells were $1 \mathrm{~cm}$ and the utilized lengths of each tubular cell were $30 \mathrm{~cm}$. Thus, the size of the stack was $50 \mathrm{~cm} \times 50 \mathrm{~cm} \times 35 \mathrm{~cm}(196$ tubular cells), larger than previously fabricated stacks (Tsai et al. 2018). However, the tubular configuration may simplify the sealing of the stack. In addition, considering the space and cost saved by removing the purification equipment and the prospects of improving LAA-SOFC performance, tubular LAA-SOFC stacks could be an attractive choice for converting solid carbon fuels.

\section{Conclusion}

Button LAA-SOFCs with different cathode materials and ratios of pore former were prepared using the APS method and measured at $750{ }^{\circ} \mathrm{C}$. The effect of the cathode structure on the electrochemical performance of cathode-down SOFCs was evaluated. A high amount of pore former in the powder during cathode fabrication decreased the polarization impedance of the cathode but increased the ohmic impedance. An optimized spraying method for LAASOFCs was developed. A tubular LAA-SOFC was prepared using this method and it reached a peak power of $2.5 \mathrm{~W}$. The tubular cell was also measured at a constant current of $2 \mathrm{~A}$ for $20 \mathrm{~h}$ and was fed sulfur-containing coal to demonstrate its impurity resistance and electrode stability.

Acknowledgements This work was supported by the National Key R\&D Program of China (2018YFB0905602), the Huaneng Group Science and Technology Research Project (HNKJ20-H50), the Beijing Natural Science Foundation Outstanding Youth Science Foundation Project (JQ18009), the National High Level Talents Special Support Plan, and the Tsinghua University Initiative Scientific Research Program.

Open Access This article is licensed under a Creative Commons Attribution 4.0 International License, which permits use, sharing, adaptation, distribution and reproduction in any medium or format, as long as you give appropriate credit to the original author(s) and the source, provide a link to the Creative Commons licence, and indicate if changes were made. The images or other third party material in this article are included in the article's Creative Commons licence, unless indicated otherwise in a credit line to the material. If material is not included in the article's Creative Commons licence and your intended use is not permitted by statutory regulation or exceeds the permitted use, you will need to obtain permission directly from the copyright holder. To view a copy of this licence, visit http://creativecommons. org/licenses/by/4.0/.

\section{References}

Cao T, Huang K, Shi Y, Cai N (2017) Recent advances in hightemperature carbon-air fuel cells. Energy Environ Sci 10:460-490. https://doi.org/10.1039/c6ee03462d

Cao T, Huang K, Shi Y, Cai N (2018) Plasma-spray derived, corrosion-resistive electrolyte for liquid antimony anode direct carbon fuel cell. J Power Sources 403:76-81. https://doi.org/10. 1016/j.jpowsour.2018.09.036

Cao T, Song P, Shi Y, Ghoniem AF, Cai N (2019) Oxy-combustion of coal in liquid-antimony-anode solid oxide fuel cell system. Proc Combust Inst 37:2841-2848. https://doi.org/10.1016/j.proci. 2018.08.056

Dong B, Li C, Liu C, Huang B, Wang Q, Fan W, Li P (2019) Integrated gasification fuel cell power generation technology with $\mathrm{CO} 2$ near zero emission and its challenges. Coal Sci Technol 47:189-193

Duan N, Cao Y, Hua B, Chi B, Pu J, Luo J, Jian L (2016) Tubular direct carbon solid oxide fuel cells with molten antimony anode and refueling feasibility. Energy 95:274-278. https://doi.org/10. 1016/j.energy.2015.10.033

Fan ESC, Kuhn J, Kesler O (2016) Suspension plasma spraying of $\mathrm{La} 0.6 \mathrm{Sr} 0.4 \mathrm{Co} 0.2 \mathrm{Fe} 0.8 \mathrm{O} 3-\delta$ cathodes: influence of carbon black pore former on performance and degradation. J Power Sources 316:72-84. https://doi.org/10.1016/j.jpowsour.2016.02.075

Fan H, Han M (2014) Electrochemical performance and stability of Sr-doped LaMnO3-infiltrated yttria stabilized zirconia oxygen 
electrode for reversible solid oxide fuel cells. Int J Coal Sci Technol 1:56-61

Harris J, Kuhn J, Kesler O (2017) Atmospheric plasma-sprayed metal-supported solid oxide fuel cells with varying cathode microstructures. J Electrochem Soc 164:F441-F447. https://doi. org/10.1149/2.1591704jes

Henne R (2007) Solid oxide fuel cells: a challenge for plasma deposition processes. J Therm Spray Technol 16:381-403. https://doi.org/10.1007/s11666-007-9053-4

Javadekar A, Jayakumar A, Pujara R, Vohs JM, Gorte RJ (2012) Molten silver as a direct carbon fuel cell anode. J Power Sources 214:239-243. https://doi.org/10.1016/j.jpowsour.2012.04.096

Jayakumar A, Javadekar A, Gissinger J, Vohs JM, Huber GW, Gorte RJ (2013) The stability of direct carbon fuel cells with molten $\mathrm{Sb}$ and Sb-Bi alloy anodes. AlChE J 59:3342-3348. https://doi.org/ 10.1002/aic. 13965

Jayakumar A, Küngas R, Roy S, Javadekar A, Buttrey DJ, Vohs JM, Gorte RJ (2011) A direct carbon fuel cell with a molten antimony anode. Energy Environ Sci 4:4133-4137. https://doi. org/10.1039/c1ee01863a

Jayakumar A, Lee S, Hornés A, Vohs JM, Gorte RJ (2010) A comparison of molten sn and bi for solid oxide fuel cell anodes. J Electrochem Soc 157:B365-B369

Jiang Y, Cao T, Shi Y, Cai N (2019) Sulfur-resistant liquid antimony anode for direct carbon fuel cells. ECS Trans 1:2001-2010. https://doi.org/10.1149/09101.2001ecst

Jiang Y, Cao T, Shi Y, Cai N (2020) Liquid antimony anode for converting sulfur-containing coal in direct carbon fuel cells. J Electrochem Soc. https://doi.org/10.1149/1945-7111/ab8bfb

Li H, Yu Yu, Han M, Lei Z (2014) Simulation of coal char gasification using O2/CO2. Int J Coal Sci Technol 1:81-87

Li M, Rao A, Brouwer J, Scott Samuelsen G (2010) Design of highly efficient coal-based integrated gasification fuel cell power plants. J Power Sources 195:5707-5718

Ma J, Duan N, Han Y, Li P, Zhu B, Yan D, Chi B, Pu J, Li J (2019) Hot corrosion of yttria-stabilized zirconia by liquid antimony and antimony oxide. J Power Sources 434:226764

Metcalfe C, Harris J, Kuhn J, Marr M, Kesler O (2013) Progress in metal-supported axial-injection plasma sprayed solid oxide fuel cells using nanostructured $\mathrm{NiO}-\mathrm{Y} 0.15 \mathrm{Zr} 0.85 \mathrm{O} 1.925$ dry powder anode feedstock. J Therm Spray Technol 22:599-608. https:// doi.org/10.1007/s11666-013-9884-0

Miruszewski T, Karczewski J, Bochentyn B, Jasinski P, Gazda M, Kusz B (2016) Determination of the ionic conductivity of Srdoped lanthanum manganite by modified Hebb-Wagner technique. J Phys Chem Solids 91:163-169. https://doi.org/10.1016/ j.jpcs.2016.01.005

Tao T, Bateman L, Bentley J, Slaney M (2007) Liquid tin anode solid oxide fuel cell for direct carbonaceous fuel conversion. ECS Trans 5:115-124
Thomas R, Manoj B (2020) Electrochemical efficacies of coal derived nanocarbons. Int J Coal Sci Technol. https://doi.org/10.1007/ s40789-020-00379-0

Tsai CH, Hwang CS, Chang CL, Nien SH, Chuang CM, Chuang Shie ZY (2014) The effect of plasma spraying power on La0.58Sr0.4$\mathrm{Co} 0.2 \mathrm{Fe} 0.8 \mathrm{O} 3-\delta$-La0.8Sr0.2Ga0.8Mg0.2O3- $\delta$ composite cathode interlayer microstructure and cell performance. Fuel Cells 14:83-90. https://doi.org/10.1002/fuce.201300143

Tsai CH, Hwang CS, Chang CL, Wu SH, Lin HH, Shiu WH, Lin JK, Yang SF, Fu CY, Yang CS (2018) Performances of plasma sprayed metal-supported solid oxide fuel cell and stack. Fuel Cells 18:800-808. https://doi.org/10.1002/fuce.201800080

Waldbillig D, Kesler O (2011) Electrochemical testing of suspension plasma sprayed solid oxide fuel cell electrolytes. J Power Sources 196:5423-5431. https://doi.org/10.1016/j.jpowsour. 2011.02 .057

Wall TF (2005) Oxy-fuel combustion technology for coal-fired power generation. Prog Energy Combust Sci 31:283-307

Wang H, Cao T, Shi Y, Cai N, Yuan W (2014a) Liquid antimony anode direct carbon fuel cell fueled with mass-produced de-ash coal. Energy 75:555-559. https://doi.org/10.1016/j.energy.2014.08.017

Wang H, Shi Y, Cai N (2013) Effects of interface roughness on a liquid-Sb-anode solid oxide fuel cell. Int $\mathrm{J}$ Hydrogen Energy 38:15379-15387. https://doi.org/10.1016/j.ijhydene.2013.09.134

Wang H, Shi Y, Cai N (2014b) Characteristics of liquid stannum anode fuel cell operated in battery mode and $\mathrm{CO} / \mathrm{H} 2 /$ carbon fuel mode. J Power Sources 246:204-212. https://doi.org/10.1016/j. jpowsour.2013.07.085

Wang H, Shi Y, Cai N (2014c) Polarization characteristics of liquid antimony anode with smooth single-crystal solid oxide electrolyte. J Power Sources 245:164-170. https://doi.org/10.1016/j. jpowsour.2013.06.125

Wang Y, Gao J, Chen W, Li C, Zhang S, Yang G, Li C (2020) Development of ScSZ electrolyte by very low pressure plasma spraying for high-performance metal-supported SOFCs. J Therm Spray Technol 29:223-231. https://doi.org/10.1007/s11666-01900970-1

Zhang S, Li C, Liu S, Li C, Yang G, He P, Yun L, Song B, Xie Y (2017) Thermally sprayed large tubular solid oxide fuel cells and its stack: geometry optimization, preparation, and performance. J Therm Spray Technol 26:441-455. https://doi.org/10.1007/ s11666-016-0506-5

Zhang S, Yu H, Li C, Lai SY, Li C, Yang G, Sun H, Wei T, Liu M (2016) Thermally sprayed high-performance porous metalsupported solid oxide fuel cells with nanostructured La0.6Sr0.4$\mathrm{Co} 0.2 \mathrm{Fe} 0.8 \mathrm{O} 3-\delta$ cathodes. J Mater Chem A 4:7461-7468. https://doi.org/10.1039/c6ta02065h

Zhu T, Wang R, Yi N, Niu W, Wang L, Xue Z (2020) $\mathrm{CO}_{2}$ and $\mathrm{SO}_{2}$ emission characteristics of the whole process industry chain of coal processing and utilization in China. Int J Coal Sci Technol 7:19-25 